\title{
Review of Research Methods for Assessing the Activity of a Municipal Landfill Based on the Landfill Gas Analysis
}

\author{
Dorota Porowska ${ }^{1 *}$ \\ ${ }^{1}$ Department of Hydrogeology, Faculty of Geology, University of Warsaw, Żwirki i Wigury 93, 02-089 Warsaw, Poland \\ * Corresponding author, e-mail: dorotap@uw.edu.pl
}

Received: 17 May 2020, Accepted: 20 July 2020, Published online: 14 January 2021

\begin{abstract}
Accurate projection of gas generation from landfills poses numerous difficulties. One needs to select and use an appropriate method from among several available options, and consider local and individual conditions of a landfill. These aspects are crucial for the economic management of the landfill gas in new landfills, and for assessing the impact of the gas on soil-water environment in old landfills. This paper is aimed at reviewing the research methods that can be used to assess the activity of new municipal waste landfills currently in operation, and of old, closed landfills after reclamation. Landfill activity can be assessed using different models and analysis of the produced gas. The actual data on the investigated municipal landfill showed that the landfill activity can be accurately assessed based on the quantitative determination of biogas formation using the LandGEM method, and the analysis of gas phase variability in the landfill accounting for oxygen, methane, carbon dioxide and hydrogen sulfide share/presence. Each landfill is different and calls for an individual approach or methodological modifications.
\end{abstract}

Keywords

landfill site, landfill gas (LFG), methane, carbon dioxide, oxygen, hydrogen sulfide

\section{Introduction}

With waste segregation schemes widely implemented, large amounts of waste are treated as secondary raw materials suitable for recycling. Properly sorted and processed waste with energy potential may serve as alternative fuels, and Chełm cement plant was one of the first in Poland to start using alternative fuels for cement production [1]. Non-recyclable waste is stored in landfills. Until recently, the landfills have served as the most common final destination point for waste that was often dumped there without any selection. The burden of a municipal waste landfill for humans and the environment depends on many factors, including the landfill age. Newly constructed facilities meet strict criteria [2-7] that keep their environmental impact to a minimum. In many countries the real problem are the landfills created in the previous century [e.g. 8-13]. After a proper reclamation the facility usually blends in perfectly with the surroundings and an above-ground landfill may be taken for a natural elevation. Despite being visually pleasing, such landfills continue to have a negative impact on the soil and water environment for many decades. Rapidly expanding urban infrastructure requires development of areas adjacent to landfills. According to the current regulations [2], once a landfill is closed, no buildings can be constructed on its top and no excavations for either above- or underground installations can be made for as long as 50 years. The landfill area can be reclaimed to serve recreational purposes, e.g. sports [14, 15]. A good example of such an approach is Górka Szczęśliwicka in Warsaw converted into a year-round ski slope. Reclaimed landfills can also be adapted to accommodate park or forest areas. Evaluation of the landfill activity and its environmental impact can substantiate the decisions on further development of such sites. It is a complex, multidirectional, and therefore interesting research topic. It requires assessment of the processes occurring in the stored waste and their impact on the immediate environment.

Assessment of changes in the processes taking place inside a landfill and estimation of the amount of generated biogas are sometimes unreliable [16]. A comparison of assessment data and actual measurements from three different landfills in northern Italy showed that the actual values were always lower than expected. In general, 
quantitative and qualitative predictions of the emissions in landfills are complicated by considerable uncertainties surrounding waste generation, in particular such aspects as public awareness and environmentally-friendly behavior, and the separation of household wastes. However, refined mathematical models are employed to assess biogas generation patterns. When fed with significant amount of reliable input data, modern models may offer a good match between the average total methane generation rates determined by field measurements and those estimated theoretically [17, 18]. Current research studies aim at improving the methods for evaluation of optimal model parameters for prediction of methane generation from landfills [19]. Monitoring methods involving observation of current biogas composition and its environmental impact have always been a reliable source of information. Many other landfills created at the same time face similar problems. Therefore, up-to-date research and exchange of experiences are immensely helpful for their operators.

Quantifying landfill gas emissions is a challenging task, due to spatial and temporal variations in emissions. Throughout the last 20 years, many approaches have been tested. This review presents simple and useful methods and assesses their advantages and disadvantages.

Its aim is to review the research methods that can be used to assess the activity of new municipal waste landfills currently in operation, and of old, closed landfills after reclamation. The key element is the analysis of landfill gas generated in biochemical processes occurring in biodegradable waste. Examples are provided based on own research (a landfill in Otwock, near Warsaw, central Poland) and available literature on this topic. Otwock landfill is located on the Vistula floodplain terrace build of higly-permeable gravels and varigrained sands. The landfill covers an area of 2.8 ha and received municipal waste in 1961-1991. Storage started at an uncontrolled landfill, so the bottom of the landfill is not lined and the type of waste is not well known. It is estimated that $300,000 \mathrm{~m}^{3}$ was deposed.

The assessment of a landfill activity includes only methods pertaining to the gas phase, and does not involve leachate analysis or contamination of soil and groundwater [20-22].

\section{Current legal regulations on landfills}

Landfill gas (LFG) is a natural by-product of decomposition of organic material in landfills. According to the Council Directive [6], landfill gas generated in landfills receiving biodegradable waste must be treated and used. If the gas quality is too low for use as fuel, then it can be flared. Venting systems should only be used where the gas quality is too low for utilization or flaring, i.e. it contains insufficient concentrations of methane and oxygen. The landfill operator is responsible for leachate measurement and the gas phase testing during operational phase. In the case of leachate detection, its volume (monthly) and composition (quarterly) need to be measured. Measurements of LFG include: $\mathrm{CH}_{4}, \mathrm{CO}_{2}, \mathrm{O}_{2}, \mathrm{H}_{2} \mathrm{~S}$ and $\mathrm{H}_{2}$ and are performed on a monthly basis. The regulation obliges the operators to perform daily measurements of the following parameters of the operational landfills: volume of precipitation, temperature, evaporation, and atmospheric humidity.

When a landfill ceases its operation and is closed (aftercare phase), the Council Directive of 1999 [6, 7] requires its monitoring for the entire period it might pose a risk. The monitoring scope is similar as in the operational stage but frequency of the measurements drops from monthly and quarterly to half-yearly intervals.

Based on the guidelines of the Council Directive [6], individual states prepare specific local requirements. For example, according to the current regulations in Poland [3], if five years after a landfill is closed, no environmental impact of the facility is detected, monitoring in the aftercare phase must only be performed every six months or less frequently. It is therefore important to know reliable methods that can be used for this assessment.

\section{Results and discussion}

\subsection{LandGEM model}

One of the methods for assessing a landfill activity is the LandGEM method recommended by the Environmental Protection Agency [23]. LandGEM is a very useful model for predicting emission rates for total landfill gas, including $\mathrm{CH}_{4}, \mathrm{CO}_{2}$, and non-methanic organic carbons (NMOCs). The method is based on a first-order exponential decay rate equation for quantifying emissions from the decomposition of landfilled waste in landfill sites. The LandGEM model is summarized by the following equation:

$$
Q_{\mathrm{CH}_{4}}=\sum_{i=1}^{n} \sum_{j=0.1}^{1} k L_{o}\left(\frac{M_{i}}{10}\right) e^{-k t_{i j}},
$$

where: $Q_{\mathrm{CH}_{4}}$ - annual methane gas generation in the year of calculation ( $\mathrm{m}^{3} /$ year)

$i$ - 1-year time increment

$n$ - initial year of waste acceptance (year of calculation)

$j-0.1$ year time increment

$k$ - methane generation rate (1/year) 
$L_{0}$ - potential methane generation capacity $\left(\mathrm{m}^{3} / \mathrm{Mg}\right)$

$M_{i}$ - mass of waste in the $i$ th year $(\mathrm{Mg})$

$i, j$ - age of the $j$ th section of waste $M_{i}$ accepted in the $i$ th year (decimal years).

Methane generation rate constant $(k)$ determines the rate of $\mathrm{CH}_{4}$ generation for each submass of waste in the landfill. The higher the value of $\mathrm{k}$, the faster $\mathrm{CH}_{4}$ generation rate increases and then decays over time. The $k$ values range from 0.002 to 0.7 (Table 1), depending on waste moisture content, availability of nutrients for methanogens, $\mathrm{pH}$, and temperature. The potential methane generation capacity $\left(L_{0}\right)$ depends only on the type and composition of waste placed in the landfill. The higher the cellulose content of the waste, the higher the value of $L_{0}$.

The following user inputs must be known to use the LandGEM method: landfill opening and closing year (or waste design capacity), and annual waste acceptance rates from the year of opening to current year or the year of closure. The data used to assess the activity of the Otwock landfill are listed in Table 2 and outcomes are presented in Fig. 1. According to the CAA regulations for conventional landfills, the default value of methane generation rate of 0.051 year and a default value of potential methane generation capacity of $170\left(\mathrm{~m}^{3} / \mathrm{Mg}\right)$ were used in the model.

According to the LandGEM method assessment, the Otwock landfill actively generates biogas even though landfilling was stopped in 1990. Gas emissions have been slowly falling since 1990 and will remain at a minimal level until around 2050-2060.

Table 1 Values for the methane generation rate $(k)$ and for the potential methane generation capacity $\left(L_{0}\right)[23]$

\begin{tabular}{lccc}
\hline Default type & Landfill type & $k(1 /$ year $)$ & $L_{0}\left(\mathrm{~m}^{3} / \mathrm{Mg}\right)$ \\
\hline CAA* $^{*}$ & Conventional & 0.05 & 170 \\
CAA* $^{*}$ & Arid Area & 0.02 & 170 \\
Inventory & Conventional & 0.04 & 100 \\
Inventory & Arid Area & 0.02 & 100 \\
Inventory & Wet (Bioreactor) & 0.7 & 96 \\
\hline
\end{tabular}

* Regulations for municipal landfills laid out by the Clean Air Act (CAA)

Table 2 Input data to assess the activity of the Otwock landfill

\begin{tabular}{lc}
\hline Inputs data & \\
\hline Landfill open year & 1961 \\
Landfill closure year & 1991 \\
(or waste design capacity) & \\
Mass of waste in the each of year & $5000 \mathrm{Mg} / \mathrm{y}$ (estimated) \\
$k(1 /$ year $)$ & 0.05 \\
$L_{0}\left(\mathrm{~m}^{3} / \mathrm{Mg}\right)$ & 170 \\
\hline
\end{tabular}

Each landfill is different and requires an individual approach. The model makes a number of assumptions, which means its results should be perceived as generalized ones. However, data on old landfills are limited (e.g. the quantity, age and composition of waste in the landfill), so the use of a more sophisticated calculation method is problematic. In this situation, the use of LandGEM method seems fully justified.

\subsection{Assessment of a landfill activity based on an analysis of gases generated by the stored waste}

One of the methods for assessing a landfill activity is to determine the stage it is in. This can be inferred taking into account the concentrations of individual gases, i.e. oxygen, carbon dioxide, methane, nitrogen and hydrogen, in the landfill gas (Fig. 2).

Their concentrations fluctuate depending on the landfill age and degradation intensity of the organic matter contained in the stored waste [22, 24-29]. Gas emissions are affected by environmental factors, such as air temperature, soil temperature and moisture content [30,31]. The organic waste degradation follows five phases (Fig. 2). In the first

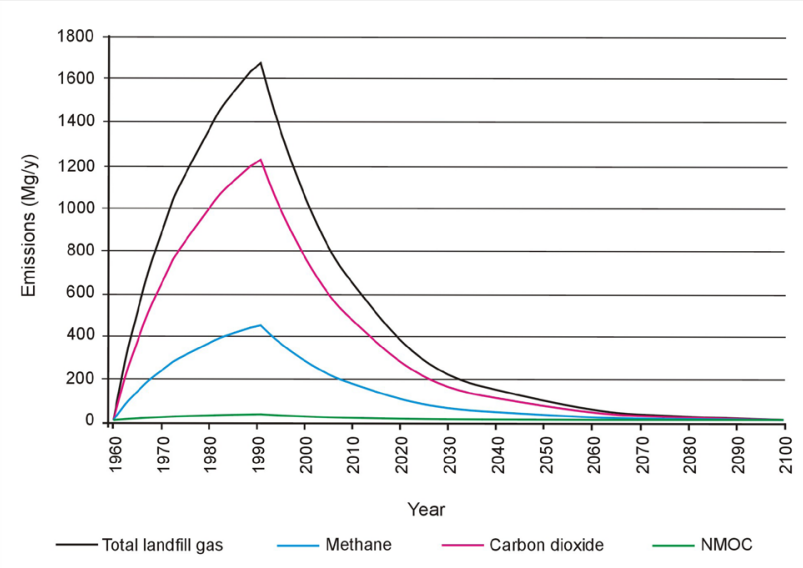

Fig. 1 Gas emission from the Otwock landfill

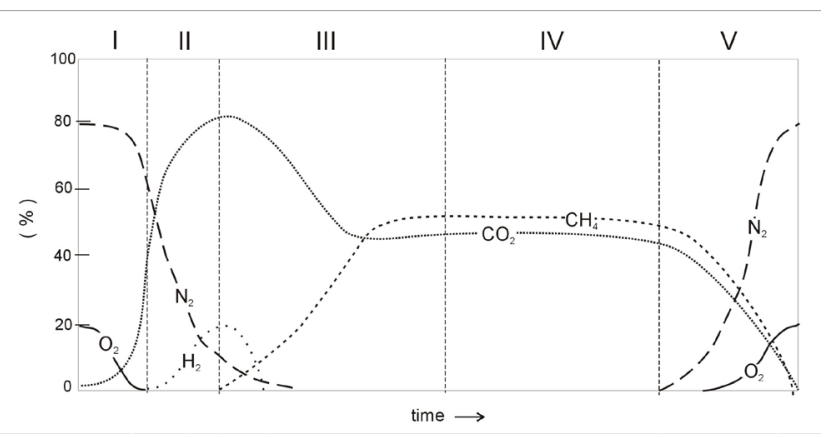

Fig. 2 Waste degradation phases in a landfill illustrating the biogas composition $[20,24,32]$ 
one, the most common products involve oxygen, nitrogen, and carbon dioxide. Concentrations of the first two gases gradually deplete, while the content of carbon dioxide rises considerably. In the second phase, oxygen disappears completely and carbon dioxide concentration increases rapidly. Nitrogen production diminishes gradually until it ceases completely in the beginning of the third phase. The third phase is when methane starts to be generated and its concentration surges speedily.

In the middle of the third phase, methane and carbon dioxide reach similar concentrations and remain at these levels throughout the fourth phase. In the fifth phase, the hydrogeochemical conditions begin to reflect those in the first phase, and the return of oxygen and nitrogen marks gradual reversion to natural conditions. The landfill phase can be determined based on the changes in generated biogas composition. However, the duration of individual phases cannot be precisely established, as it strongly depends on the landfill parameters (landfill type, waste storage method, type and amount of waste, etc.), as well as geological, hydrogeological, and climatic conditions.

The processes that control the gas phase composition inside the landfill are not seasonal and their course is not weather dependent as in the case of natural environment. They are of individual nature that depends on the time of the waste submission and exothermic reactions inside the landfill $[33,34]$. Gas emission were measured in 6 gas wells located within the landfill. Gastec field kit (Gastec Corporation Japan) was used for gas measurement.

\subsubsection{Oxygen}

Oxygen is a component of the landfill gas in the initial and final stage of the facility operation. It is rapidly utilized by aerobic microorganisms, which is why it is absent in the second, third and fourth phase. Due to this characteristic changes over time, oxygen is immensely helpful in assessing the landfill phase. Its re-appearance in the landfill gas after many years indicates the return of the natural environmental conditions.

The studies of the Otwock landfill showed variable content of oxygen depending on the measurement point and season. In 1999 its concentration ranged from $0.39 \%$ to $0.69 \%$, while in May and July 2006 it reached its maximum of $19 \%$ (Table 3). Spatial distribution analysis revealed the lowest concentrations of oxygen in the central part of the landfill, and the highest at its borders. In subsequent measurement periods oxygen concentrations were below the limit of quantification of the applied measurement method $(<0.5 \%)$. In January 2020, oxygen concentration changed to $1 \%$. This may indicate both a slightly decreased intensity of biochemical processes due to alterations of hydrochemical conditions in the waste pile (waste drying in the border zone), and a gradual progress towards the fifth stage.

A study involving seven landfills in Great Britain demonstrated oxygen concentration in the landfill gas below $1 \%$ (limit of quantification of the method), thus indicating active biochemical processes in the stored waste that under reducing conditions result in the formation of methane [39].

\subsubsection{Methane}

Methane is formed as a result of anaerobic degradation of organic matter. It may be generated during natural decomposition of organic compounds, e.g. in peatlands, or in purposely constructed facilities for storing organic matter, such as municipal waste landfills. It can be dangerous, as it is prone to spontaneous ignition and may also explode if its volume concentration in the air exceeds $5 \%$. Methane concentration may be determined with multiple methods [40].

Methane share in the landfill gas is variable but usually ranges between $50 \%$ and $65 \%$. The gas appears in the third phase, when its concentration gradually increases

Table 3 Field measurements of oxygen concentration in the landfill gas

\begin{tabular}{|c|c|c|c|c|c|c|c|c|c|}
\hline \multirow[b]{2}{*}{$\begin{array}{l}\text { No well } \\
\text { gas }\end{array}$} & \multicolumn{9}{|c|}{ Oxygen concentrations $(\%)$} \\
\hline & $\begin{array}{c}8.11 . \\
1999 *\end{array}$ & $\begin{array}{c}25.05 . \\
2006^{* *}\end{array}$ & $\begin{array}{c}11.07 . \\
2006^{* *}\end{array}$ & $\begin{array}{c}23.08 \\
2006^{* *}\end{array}$ & $\begin{array}{c}8.12 . \\
2006^{* * * *}\end{array}$ & $\begin{array}{c}6.03 . \\
2007 * * *\end{array}$ & $\begin{array}{c}6.08 . \\
2013^{* * *}\end{array}$ & $\begin{array}{c}14.09 . \\
2019\end{array}$ & $\begin{array}{r}24.01 \\
2020\end{array}$ \\
\hline 1 & 0.40 & 1 & $<0.5$ & $<0.5$ & $<0.5$ & $<0.5$ & $<0,5$ & $<0.5$ & 1 \\
\hline 2 & 0.39 & 1 & 4.2 & $<0.5$ & $<0.5$ & $<0.5$ & $<0,5$ & $<0.5$ & $<0.5$ \\
\hline 3 & 0.53 & 4.5 & 16 & $<0.5$ & $<0.5$ & $<0.5$ & $<0,5$ & $<0.5$ & $<0.5$ \\
\hline 4 & 0.60 & 6 & $<0.5$ & $<0.5$ & $<0.5$ & $<0.5$ & $<0,5$ & $<0.5$ & $<0.5$ \\
\hline 5 & 0.89 & 10.5 & $<0.5$ & $<0.5$ & $<0.5$ & $<0.5$ & $<0,5$ & $<0.5$ & 1 \\
\hline 6 & 0.86 & 12 & 19 & $<0.5$ & $<0.5$ & $<0.5$ & $<0,5$ & $<0.5$ & $<0.5$ \\
\hline
\end{tabular}

*Koda et al. [35]; **Porowska and Gruszczyński [36, 37]; ***Porowska [38] 
(Fig. 2). The high level of methane is maintained in the fourth phase, then it gradually declines to disappear completely at the end of the fifth phase. An important process affecting methane and carbon dioxide content is the oxidation of methane. The process depends on the climatic conditions, particularly temperature and precipitation amount translating into the moisture content of the stored waste. Its intensity is high in the summer at temperatures of $25-30^{\circ} \mathrm{C}$ and moisture content of 10-20\% [41]. Higher moisture content, up to $45 \%$, also facilitates the oxidation of methane [42]. Temperature and soil moisture seem to be the crucial environmental factors affecting the methane oxidizing capacity of a landfill cover soil [43]. Based on the Statistical Model, Héroux et al. [44] showed a significant statistical effect of the three factors: 1) temperature, 2) soil moisture content, and 3) pressure gradient between the waste and the atmosphere and the interaction between temperature and soil moisture content on methane emissions.

Measurements of methane emissions in nine active municipal waste landfills in north-east United States revealed that the gas recovery reduced methane atmospheric emission by up to 10 times [45]. The gas recovery efficiency determined by field measurements was 59-76\% [17]. A minimum methane mitigation efficiency of $80 \%$ is suggested [46].

The economic profitability of the biogas recovery is reduced by its oxidation and migration out of its formation zone in the landfill. Methane oxidation rate in the soil depends on several environmental factors, among which the most important are layer properties (porosity, permeability, and diffusivity), moisture content, and temperature [47]. The major mechanisms for gas transport through the cover soil are diffusion and advection. Diffusive transport is facilitated by a concentration gradient through the soil, whereas advective transport results from pressure gradients induced by wind, changing barometric pressure, or internal pressure buildup from landfill generation [48, 49]. A study by Chanton et al. [50] indicated that the fraction of methane oxidized in a landfill exceeded $10 \%$.

Monitoring of the zone adjacent to an old landfill in Denmark revealed significant seasonal variability of emissions, with high levels of carbon dioxide and low levels of methane in the summer (from May to October), resulting from the oxidation of methane (demonstrated based on calculations and carbon isotopic analysis) [17].

As methane can be generated both in natural and anthropogenic processes, simple measurements of its concentration are not accurate enough. The genesis of methane carbon can be traced down by means of isotope studies.
Carbon isotope measurements are useful in assessing methane oxidation, because significant isotopic fractionation occurs when methane is oxidized to carbon dioxide. The fraction of oxidized methane (fo) can be calculated using Eq. 2 [51]:

$$
f_{o}=\left(\frac{\delta E-\delta A}{(\alpha-1) 1000}\right),
$$

where: $\delta E$ - isotopic composition of the emission zone $\left(\delta^{13} C\right)$

$$
\begin{aligned}
& \delta A \text { - isotopic composition of the anoxic zone }\left(\delta^{13} C\right) \\
& \alpha \text { - fractionating factor (e.g. } \alpha=1.022-1.031)
\end{aligned}
$$

According to the observations of Christophersen et al. [51], the average annual methane oxidation is $17-56 \%$. Aghdam et al. [17] demonstrated that the methane oxidation efficiency is $6-37 \%$, with an average of $18 \%$.

Depending on the entire spectrum of complex conditions concerning the landfill and its age, the methane generated in the landfill reaches negative values of $\delta^{13} C_{\mathrm{CH} 4}$, ranging from -60 to $-34.5 \%$, while carbon dioxide usually reaches positive values exceeding even $+18.4 \%$ o (Table 4 ).

Studies on isotopic composition of methane in peatlands usually indicate values from -70 to $-60 \%$ [ [38], with considerably wider range of extreme values from -110 to $-50 \%$ [62-64].

\begin{tabular}{|c|c|c|c|}
\hline Location & $\delta^{13} C_{\mathrm{CH} 4}(\% 0)$ & $\delta^{13} C_{\mathrm{CO} 2}(\% 0)$ & Reference \\
\hline USA & from -56 to -48 & from -9 to +18 & {$[52-54]$} \\
\hline Illinois & from -57 to -53.3 & from +8.2 to +14.0 & {$[52]$} \\
\hline West US & $\begin{array}{c}\text { from }-60.0 \\
\text { to }-58.8\end{array}$ & from +9.5 to +9.6 & \\
\hline East US & from -55.5 to -51.0 & from -7.4 to +12.4 & \\
\hline Indiana & $\begin{array}{c}\text { from }-52.1 \\
\text { to }-48.5\end{array}$ & $\begin{array}{c}\text { from }+16.1 \text { to } \\
+16.6\end{array}$ & [55] \\
\hline Delaware & - & $\begin{array}{c}\text { from }+10.3 \text { to } \\
+18.4\end{array}$ & {$[56]$} \\
\hline California & - & +5.45 and +10.19 & {$[57]$} \\
\hline $\begin{array}{l}\text { New England } \\
\text { (United State) }\end{array}$ & $\begin{array}{c}\text { from }-56.8 \\
\text { to }-41.3\end{array}$ & - & [58] \\
\hline $\begin{array}{l}\text { Leon County, } \\
\text { Florida }\end{array}$ & $\begin{array}{c}\text { from }-55.4 \\
\text { to }-34.5\end{array}$ & - & {$[59]$} \\
\hline $\begin{array}{l}\text { Germany, } \\
\text { Netherlands }\end{array}$ & $-55.4 \pm 1.4$ & - & {$[60]$} \\
\hline Falköping & $\begin{array}{l}-54.3 \pm 0.1 \\
-53.6 \pm 1.7\end{array}$ & - & {$[61]$} \\
\hline Hökhuvud & $\begin{array}{l}-43.3 \pm 0.1 \\
-58.6 \pm 1.4\end{array}$ & - & {$[01]$} \\
\hline
\end{tabular}

Table 4 Isotopic composition of gas phase carbon $-\mathrm{CO}_{2}$ and $\mathrm{CH}_{4}$ in a landfill 


\subsubsection{Carbon dioxide}

The share of carbon dioxide in landfill gas varies depending on the phase the landfill is in (Fig. 2). Its highest concentrations, reaching even $80 \%$, occur at the turn of the second and third phase. Measurements in seven landfills in Great Britain revealed $\mathrm{CO}_{2}$ concentration varying from 24 to $42 \%$ [39]. The landfill in Otwock showed large spatial and temporal variability (Table 5), resulting from changing activity of geochemical processes inside the landfill that depended on variability of local conditions over time.

Other researchers showed also variable activity of the same landfill throughout the year [65-67]. Geochemical and isotopic measurements carried out at the Bariloche landfill in Argentina, demonstrated variable rate of biodegradation depending on the place of waste storage at a given time, from aerobic decomposition of organic compounds in the most recently deposited waste to the reduction processes (methanogenesis) in the oldest part of the landfill [67].

Carbon dioxide may diffuse into the atmosphere or migrate into the groundwater in a dissolved form of bicarbonate. Under anaerobic conditions it can be also reduced to methane and can be transferred in this form. The content of carbon dioxide depends on the availability of oxygen and parameters of the soil medium allowing for gas migration.

\subsubsection{Other gases}

In addition to the gases characterized above, landfill gas contains numerous volatile organic compounds (VOCs) and reduced sulfur compounds (RSC) [39, 68, 69]. These VOCs include primarily alkanes (e.g., butane), aromatic compounds (e.g., toluene, xylenes), and chlorinated hydrocarbons (e.g., chlorobenzene) [69, 70]. Volatile organic compounds disposed in landfills may escape to the atmosphere via diffusion across the landfill cover [21]. In landfill gas, sulfur compounds occur in reduced forms: hydrogen sulfide $\left(\mathrm{H}_{2} \mathrm{~S}\right)$, methyl mercaptan $\left(\mathrm{CH}_{3} \mathrm{SH}\right)$, dimethyl sulfide $\left(\left(\mathrm{CH}_{3}\right)_{2} \mathrm{~S}\right)$, carbon disulfide $\left(\mathrm{CS}_{2}\right)$, and dimethyl disulfide $\left.\left(\left(\mathrm{CH}_{3}\right)_{2} \mathrm{~S}_{2}\right)\right)[71]$.

As per the EU Directive [6], hydrogen sulfide should be monitored. It is a useful parameter of a landfill activity, as its content in the biogas changes with the landfill age. It is much more abundant in new landfills than in those operating for many years. The mean value of $\mathrm{H}_{2} \mathrm{~S}$ in a young landfill was determined to be about 139 ppm, while in an old landfill it was only $0.0039 \mathrm{ppm}$ [72]. The analysis of hydrogen sulfide concentrations in the biogas collection wells in the Otwock landfill showed considerable spatial variability over a 20-year observation period (Table 6). The lowest values did not exceed $0.25 \mathrm{ppm}$, while the highest reached $47 \mathrm{ppm}$. In comparison with hydrogen sulfide concentrations in new and old facilities studied by Kim [72], $\mathrm{H}_{2} \mathrm{~S}$ levels recorded for the Otwock landfill fell in between but were still closer to the new and therefore active landfills.

Given the period of the Otwock landfill operation, it can be classified as an old facility, and therefore low share of hydrogen sulphide in the biogas was expected. According to a common classification used e.g. by Renou et al. [73] or Alvarez-Vazqueza et al. [74], the landfills whose operation ceased more than 10 years ago are treated as old ones. However, hydrogen sulfide content in the biogas indicated that the the Otwock landfill was still active, and the expected return to natural conditions has not happened yet.

\section{Conclusions}

Landfill activity can be assessed based on model studies and quantitative and qualitative analysis of the generated landfill gas. The Environmental Protection Agency recommends using the LandGEM model, which allows for forecasting the generation of total landfill gas, including $\mathrm{CH}_{4}, \mathrm{CO}_{2}$ and non-methanic organic carbons. The method requires little input data (years of the facility operation

Table 5 Field measurements of carbon dioxide concentration in the landfill gas

\begin{tabular}{|c|c|c|c|c|c|c|c|c|c|}
\hline \multirow[b]{2}{*}{ No well gas } & \multicolumn{9}{|c|}{ Carbon dioxide concentrations (\%) } \\
\hline & $\begin{array}{c}8.11 . \\
1999 *\end{array}$ & $\begin{array}{c}25.05 \\
2006 * *\end{array}$ & $\begin{array}{c}11.07 . \\
2006^{* *}\end{array}$ & $\begin{array}{c}23.08 \\
2006^{* *}\end{array}$ & $\begin{array}{c}8.12 . \\
2006^{* *}\end{array}$ & $\begin{array}{c}6.03 \\
2007 * *\end{array}$ & $\begin{array}{l}6.08 \\
2013\end{array}$ & $\begin{array}{c}14.09 . \\
2019\end{array}$ & $\begin{array}{c}24.01 . \\
2020\end{array}$ \\
\hline 1 & 17.3 & 8.5 & 13.0 & 18.0 & 10.0 & 15.0 & 12.5 & 12.0 & 8.5 \\
\hline 2 & 16.5 & 12.0 & 11.0 & 22.0 & 14.0 & 19.0 & 12.0 & 8.0 & 14.0 \\
\hline 3 & 20.7 & 26.0 & 1.3 & 30.0 & 18.0 & 26.0 & 19.0 & 5.0 & 21.0 \\
\hline 4 & 22.3 & 14.5 & 15.0 & 30.0 & 17.5 & 22.0 & 26.0 & 5.5 & 20.0 \\
\hline 5 & 18.9 & 18.0 & 13.6 & 21.0 & 14.5 & 22.0 & 18.0 & 8.0 & 5.0 \\
\hline 6 & 20.3 & 14.0 & 1.0 & 29.0 & 14.5 & 24.5 & 12.0 & 11.0 & 8.0 \\
\hline
\end{tabular}

*Koda et al. [35]; **Porowska and Gruszczyński [36, 37] 
Table 6 Field measurements of hydrogen sulfide concentration in the landfill gas

\begin{tabular}{|c|c|c|c|c|c|c|c|c|c|}
\hline \multirow[b]{2}{*}{ No well gas } & \multicolumn{9}{|c|}{ Hydrogen sulfide concentrations (ppm) } \\
\hline & $\begin{array}{c}8.11 . \\
1999 *\end{array}$ & $\begin{array}{c}25.05 \\
2006^{* *}\end{array}$ & $\begin{array}{c}11.07 \\
2006^{* *}\end{array}$ & $\begin{array}{c}23.08 \\
2006^{* *}\end{array}$ & $\begin{array}{c}8.12 . \\
2006^{* * *}\end{array}$ & $\begin{array}{c}6.03 . \\
2007 * * *\end{array}$ & $\begin{array}{c}6.08 . \\
2013^{* * *}\end{array}$ & $\begin{array}{c}14.09 . \\
2019\end{array}$ & $\begin{array}{c}24.01 . \\
2020\end{array}$ \\
\hline 1 & 7.1 & 2 & $<0.25$ & 23 & 4.5 & 5 & 5 & $<0.25$ & 8 \\
\hline 2 & 5.8 & 4 & $<0.25$ & 16 & 12 & 6 & 8 & 2 & 5 \\
\hline 3 & 15.0 & 8 & $<0.25$ & 20 & 8 & 23 & 12 & 2 & 6 \\
\hline 4 & 5.3 & 8 & 4 & 10 & 8 & 11 & 8 & $<0.25$ & 5 \\
\hline 5 & 0.4 & 2 & $<0.25$ & 16 & 13 & 11 & 6 & 4 & $<0.25$ \\
\hline 6 & 3.0 & 3 & $<0.25$ & 7 & 47 & 47 & 10 & $<0.25$ & 20 \\
\hline
\end{tabular}

*Koda et al. [35]; **Porowska and Gruszczyński [36, 37]; ***Porowska [38]

and the amount of waste deposited per individual years), which makes it attractive especially for biogas analysis in old facilities, where there were no procedures followed for waste storage and that are now lacking data required by more complex models. It should be, however, remembered that the results of such a general model as LandGEM are for information purposes only and provide just approximate data on the landfill biogas.

The methods used for accurate assessment of the landfill activity involve gas phase analysis with the measurement of oxygen, methane, carbon dioxide and hydrogen sulfide. The results are the most precise when all gases are determined simultaneously (due to cross play between methane, oxygen and carbon dioxide), and at different seasons (due to various hydrogeochemical conditions in the stored waste). The processes resulting in biogas formation of different quantity and composition are prone to seasonal changes in intensity brought about by many factors, such as moisture content, air temperature, atmospheric pressure, redox conditions, and precipitation $\mathrm{pH}$. This is due to the fact that a landfill is an active environment for microbiological transformations closely correlating with the landfill water balance. Gas phase analysis allows for precise and reliable assessment of the landfill activity. However, it requires several measurements to be carried out under different humidity, temperature and pressure conditions.

\section{References}

[1] CEMEX "Cementownia Chełm" (Chełm Cement Plant), [online] Available at: https://www.cemex.pl/cementownia-chelm.aspx [Accessed: 02 February 2020] (in Polish)

[2] Government Legislation Center "Rozporządzenie Ministra Środowiska z dnia 30 kwietnia 2013 r. w sprawie składowisk odpadów" (Regulation of the Minister of Environment of 30 April 2013 on waste landfills), Journal of Laws, Item 523, 2013. [online] Available at: https://dziennikustaw.gov.pl/DU/rok/2013/ pozycja/523 [in Polish]
Each landfill is different and requires an individual approach, especially in the case of different operating times. New landfills currently in operation need a different methodological approach than the old and reclaimed ones, which is mostly due to different waste composition reflected in the content of individual gases in the landfill biogas. Currently, the landfills are supplied with greater amount of waste with long degradation times. Another important factor is the amount of the waste that determines the amount of the generated biogas and allows for economic assessment of its use or disposal via passive degassing.

When assessing the general impact of a landfill on hydrogeological environment, one needs to remember that the gases and leachate formed in the landfill penetrate into the soil and groundwater. Even when the intensity of decomposition processes in the landfill slows down, they will still be detected as groundwater pollutions downstream of the landfill. Therefore, intensity of biochemical processes in the landfill may gradually cease but the pollutants released into the aquifer may still be present in high concentrations.

\section{Acknowledgement}

The research was supported by the Faculty of Geology at the University of Warsaw.

[3] Government Legislation Center "Ustawa z dnia 23 stycznia 2020 r. o zmianie ustawy o odpadach oraz niektórych innych ustaw" (Act of 23 January 2020 amending the act on waste and certain other acts), Journal of Laws, Item 150, 2020. [online] Available at: https://dziennikustaw.gov.pl/DU/rok/2020/pozycja/150 [in Polish] 
[4] Klimek, A., Wysokiński, L., Zawadzka-Kos, M., Osęka, M., Chrząszcz, J. "Poradnik metodyczny w zakresie PRTR dla składowisk odpadów komunalnych" (Methodical guide in the field of PRTR for municipal landfills), Narodowy Fundusz Ochrony Środowiska i Gospodarki Wodnej - NFOŚiGW (National Fund for Environmental Protection and Water Management), Warsaw, Poland, 2010. [in Polish]

[5] NIK "Zamykanie i rekultywacja składowisk odpadów niespełniających wymagań prawnych, KSI-4101-004-00/2014" (Closing and reclamation of landfills that do not meet legal requirements, KSI-4101-004-00/2014), [pdf] Department of the Environment (Supreme Chamber of Control), Warsaw, Poland, Available at: https://www.nik.gov.pl/plik/id,9386,vp,12116.pdf [Accessed: 16 March 2020] (in Polish)

[6] The Council of the European Union "Council Directive 1999/31/ EC of 26 April 1999 on the landfill of waste", Official Journal L 182, pp. 1-19, 1999. [online] Available at: http://data.europa.eu/eli/ dir/1999/31/oj [Accessed: 16 March 2020]

[7] The European Parliament and the Council of the European Union "Directive (EU) 2018/850 of the European Parliament and of the Council of 30 May 2018 amending Directive 1999/31/EC on the landfill of waste", Official Journal of the European Union, L 150/100, 2018. [online] Available at: http://data.europa.eu/eli/ dir/2018/850/oj [Accessed: 16 March 2020]

[8] Prantl, R., Tesar, M., Huber-Humer, M., Lechner, P. "Changes in carbon and nitrogen pool during in-situ aeration of old landfills under varying conditions", Waste Manage, 26(4), pp. 373-380, 2006. https://doi.org/10.1016/j.wasman.2005.11.010

[9] Ritzkowski, M., Heyer, K.-U., Stegmann, R. "Fundamental processes and implications during in situ aeration of old landfills", Waste Manage, 26(4), pp. 356-372, 2006.

https://doi.org/10.1016/j.wasman.2005.11.009

[10] Witkowski, A. J., Żurek, A. M. "Wpływ starych, zrekultywowanych składowisk odpadów komunalnych na wody podziemne" (Impact of Old Remediated Sanitary Landfills on Groundwater), In: Szczepański, A., Kmiecik, E., Żurek, A. (eds.) Współczesne Problemy Hydrogeologii, 13, AGH, Krakow, Poland, 2007, pp. 625-633. [in Polish]

[11] Cozzarelli, I. M., Böhlke, J. K., Masoner, J. R., Breit, G. N., Lorah, M. M., Tuttle, M. L., Jaeschke, J. B. "Biogeochemical evolution of a landfill leachate plume, Norman, Oklahoma", Ground Water, 49(5), pp. 663-687. 2011.

https://doi.org/10.1111/j.1745-6584.2010.00792.x

[12] Masoner, J. R., Cozzarelli, I. M. "Spatial and Temporal Migration of a Landfill Leachate Plume in Alluvium", Water Air Soil Pollution, 226, Article number: 18, 2015. https://doi.org/10.1007/s11270-014-2261-x

[13] Porowska, D. "Assessment of a degree of geochemical maturation and activity of a closed landfill site in Poland", Environmental Earth Sciences, 75, Article number: 331, 2016. https://doi.org/10.1007/s12665-016-5256-7

[14] Wysokiński, L. "Budowa, modernizacja i rekultywacja składowisk odpadów komunalnych" (Construction, modernization and reclamation of municipal waste landfills), Municipal Review, 4(79), pp. 3-34, 1998. [in Polish]
[15] Koda, E. "Procedury techniczno-technologiczne stawiane zamykaniu i rekultywacji składowisk odpadów komunalnych" (Technical and technological procedures for closing and reclamation of municipal waste landfills), In: Proocedings of the National Conference Recultivation of Landfills, Ekorum, Poznań, Poland, 2014, pp. 35-55. [in Polish]

[16] Gendolla, M., Acaia, C., Fisher, C. "Landfill gas migration in the subsoil: experiences of control and remediation", In: Uhre, L. (ed.) International directory of solid waste management 1997/8, The ISWA yearbook, James \& James Science Publisher, London, UK, 2002, pp. 237-245.

[17] Aghdam, E. F., Fredenslund, A. M., Chanton, J., Kjeldsen, P., Scheutz, C. "Determination of gas recovery efficiency at two Danish landfills by performing downwind methane measurements and stable carbon isotope isotopic analysis", Waste Management, 73, pp. 220-229, 2018.

https://doi.org/10.1016/j.wasman.2017.11.049

[18] Ahmadi, N., Mosthaf, K., Scheutz, C., Kjeldsen, P., Rolle, M. "Model-based interpretation of methane oxidation and respiration processes in landfill biocovers: 3-D simulation of laboratory and pilot experiments", Waste Management, 108, pp. 160-171, 2020. https://doi.org/10.1016/j.wasman.2020.04.025

[19] Sun, W., Wang, X., DeCarolis, J. F., Barlaz, M. A. "Evaluation of optimal model parameters for prediction of methane generation from selected U.S. landfills", Waste Management, 91, pp. 120-127, 2019. https://doi.org/10.1016/j.wasman.2019.05.004

[20] Christensen, T. H., Kjeldsen, P. "Basic Biochemical Processes in Landfills", In: Sanitary Landfilling: Process, Technology and Environmental Impact", Academic Press, San Diego, CA, USA, pp. 29-49, 1989.

https://doi.org/10.1016/B978-0-12-174255-3.50008-6

[21] Kjeldsen, P., Christensen, T. H. "A simple model for the distribution and fate of organic chemicals in a landfill: MOCLA", Waste Management and Research, 19(3), pp. 201-216, 2001. https://doi.org/10.1177/0734242X0101900303

[22] Kjeldsen, P., Barlaz, M. A., Rooker, A. P., Baun, A., Ledin, A., Christensen, T. H. "Present and Long-Term Composition of MSW Landfill Leachate: A Review", Critical Reviews in Environmental Science and Technology, 32(4), pp. 297-336, 2002. https://doi.org/10.1080/10643380290813462

[23] EPA United States Environmental Protection Agency "Landfill Gas Emissions Model (LandGEM) Version3.02 User's Guide", [pdf] Available at: https://www3.epa.gov/ttn/catc/dir1/landgemv302-guide.pdf [Accessed: 10 February 2020]

[24] Farquhar, G. J., Rovers, F. A. "Gas production during refuse decomposition", Air, Water, and Soil Pollution, 2, pp. 483-495, 1973. https://doi.org/10.1007/BF00585092

[25] Rees, J. F. "The fate of carbon compounds in the landfill disposal of organic matter", Journal of Chemical Technology and Biotechnology, 30(1), pp. 161-175, 1980. https://doi.org/10.1002/jctb.503300121

[26] Bogner, J., Spokas, K. "Landfill CH4: Rates, Fates, and Role in Global Carbon Cycle", Chemosphere, 26(1-4), pp. 369-386, 1993. https://doi.org/10.1016/0045-6535(93)90432-5 
[27] Walsh, D. C., LaFleur, R. G., Bopp, R. F. "Stable carbon isotopes in dissolved inorganic carbon of landfill leachate", Ground Water Manage, 16, pp. 153-167, 1993.

[28] Börjesson, G., Svensson, G. H. "Seasonal and Diurnal Methane Emissions From a Landfill and Their Regulation By Methane Oxidation", Waste Management and Research, 15(1), pp. 33-54, 1997.

\section{https://doi.org/10.1177/0734242X9701500104}

[29] Vargha, V., Rétháti, G., Heffner, T., Pogácsás, K., Korecz, L., László, Z., Czinkota, I., Tolner, L., Kelemen, O. "Behavior of Polyethylene Films in Soil", Periodica Polytechnica Chemical Engineering, 60(1), pp. 60-68, 2016.

https://doi.org/10.3311/PPch.8281

[30] Wang, X., Jia, M., Lin, X., Xu, Y., Ye, X., Kao, C.M., Chen, S. "A comparison of $\mathrm{CH} 4, \mathrm{~N} 2 \mathrm{O}$ and $\mathrm{CO} 2$ emissions from three different cover types in a municipal solid waste landfill", Journal of the Air \& Waste Management Association, 67(4), pp. 507-515, 2017. https://doi.org/10.1080/10962247.2016.1268547

[31] Izumoto, S., Hamamoto, S., Kawamoto, K., Nagamori, M., Nishimura, T. "Monitoring of methane emission from a landfill site in daily and hourly time scales using an automated gas sampling system", Environmental Science and Pollution Research, 25(24), pp. 24500-24506, 2018.

https://doi.org/10.1007/s11356-018-2671-1

[32] Hester, R. E., Harrison, R. M. (eds.) "Environmental and Health Impact of Solid Management Actives", Royal Society of Chemistry, London, UK, 2002. https://doi.org/10.1039/9781847550767

[33] North, J. C., Frew, R. D. "Isotopic Characterization of Leachate from Seven New Zealand Landfills", In: Lehmann, E. C. (ed.) Landfill Research Focus, Nova Science Publishers, New York, NY, USA, 2007, pp. 55-82.

[34] Yeşiller, N., Hanson, J. L., Yee, E. H. "Waste heat generation: A comprehensive review", Waste Management, 42, pp. 166-179, 2015. https://doi.org/10.1016/j.wasman.2015.04.004

[35] Koda, E., Augustyniak, E., Pachuta, K., Paprocki, P. "Ocena oddziaływania na środowisko nieczynnego wysypiska odpadów stałych w Otwocku, woj. mazowieckie" (Environ-mental impact assessment of a closed landfill in Otwock, Masovian Voivodeship), GEOTEKO, Warsaw, Poland, 1999. [in Polish]

[36] Porowska, D., Gruszczyński, T. "Zmienność składu fazy gazowej składowiska odpadów komunalnych w Otwocku" (Variation of gas composition within the Otwock landfill, central Poland), Geological Review, 54(11), pp. 996-1001, 2006. [in Polish]

[37] Porowska, D., Gruszczyński, T. "Czynniki warunkujące zmiennosć składu fazy gazowej składowiska odpadów komunalnych w Otwocku" (Factors controlling changes of gas composition within the Otwock landfill), Biuletyn PIG, 456(XVI/2), pp. 457-464, 2013. [in Polish]

[38] Porowska, D. "Geneza węgla nieorganicznego w wodach podziemnych strefy hipergenezy $w$ warunkach naturalnych i przekształconych antropogenicznie na przykładzie poligonów Pożary i Otwock" (The origin of inorganic carbon in groundwater within hypergenesis zone in natural and anthropogenically changed conditions on the base of Pożary and Otwock research fields), Publishing House of the University of Warsaw, Warsaw, Poland, 2016. [in Polish]
[39] Allen, M. R., Braithwaite, A., Hills, C. C. "Trace Organic Compounds in Landfill Gas at Seven U.K. Waste Disposal Sites", Environmental Science and Technology, 31(4), pp. 1054-106. 1997. https://doi.org/10.1021/es 9605634

[40] Mønster, J., Kjeldsen, P., Scheutz, C. "Methodologies for measuring fugitive methane emissions from landfills - A review", Waste Management, 87, pp. 835-859, 2019. https://doi.org/10.1016/j.wasman.2018.12.047

[41] Stern, J. C., Chanton, J., Abichou, T., Powelson, D., Yuan, L., Escoriza, S., Bogner, J. "Use of biologically active cover to reduce landfill methane emissions and enhance methane oxidation", Waste Management, 27(9), pp. 1248-1258, 2007. https://doi.org/10.1016/j.wasman.2006.07.018

[42] Hilger, H., Humer, M. "Biotic Landfill Cover Treatments for Mitigating Methane Emissions", Environmental Monitoring and Assessment, 84, pp. 71-84, 2003. https://doi.org/10.1023/A:1022878830252

[43] De Visscher, A., Van Cleemput, O. "Simulation model for gas diffusion and methane oxidation in landfill cover soils", Waste Management, 23(7), pp. 581-591, 2003. https://doi.org/10.1016/S0956-053X(03)00096-5

[44] Héroux, M., Guy, C., Millette, D. "A Statistical Model for Landfill Surface Emissions", Journal of the Air \& Waste Management Association, 60(2), pp. 219-228, 2010. https://doi.org/10.3155/1047-3289.60.2.219

[45] Mosher, B. W., Czepiel, P. M., Harriss, R. C., Shorter, J. H., Kolb, C. E., McManus, J. B., Allwine, E., Lamb, B. K. "Methane Emissions at Nine Landfill Sites in the Northeastern United States", Environmental Science \& Technology, 33(12), pp. 2088-2094, 1999. https://doi.org/10.1021/es981044z

[46] Scheutz, C., Kjeldsen, P. "Guidelines for landfill gas emission monitoring using the tracer gas dispersion method", Waste Management, 85, pp. 351-360, 2019. https://doi.org/10.1016/j.wasman.2018.12.048

[47] Scheutz, C., Kjeldsen, P., Bogner, J. E., De Visscher, A., Gebert, J., Hilger, H. A., Huber-Humer, M., Spokas, K. "Microbial methane oxidation processes and technologies for mitigation of landfill gas emissions", Waste Management \& Research, 27(5), pp. 409-455, 2009. https://doi.org/10.1177/0734242X09339325

[48] Czepiel, P. M., Shorter, J. H., Mosher, B., Allwine, E., McManus, J. B., Harriss, R. C., Kolb, C. E., Lamb, B. K. "The influence of atmospheric pressure on landfill methane emissions", Waste Management, 23, pp. 593-598, 2003. https://doi.org/10.1016/S0956-053X(03)00103-X

[49] Morris, J. W. F., Caldwell, M. D., Obereiner, J. M., O'Donnell, S. T., Johnson, T. R., Abichou, T. "Modeling methane oxidation in landfill cover soils as indicator of functional stability with respect to gas management", Journal of the Air \& Waste Management Association, 69(1), pp. 13-22, 2019. https://doi.org/10.1080/10962247.2018.1500403

[50] Chanton, J. P., Powelson, D. K., Green, R. B. "Methane oxidation in landfill cover soils, is a $10 \%$ default value reasonable?", Journal of Environmental Quality, 38(2), pp. 654-663, 2009. https://doi.org/10.2134/jeq2008.0221 
[51] Christophersen, M., Kjeldsen, P., Holst, H., Chanton, J. "Lateral gas transport in soil adjacent to an old landfill: factors governing emissions and methane oxidation", Waste Management and Research, 19(6), pp. 595-612, 2001. https://doi.org/10.1177/0734242X0101900616

[52] Hackley, K. C., Liu, C. L., Coleman, D. D. "Environmental isotope characteristics of landfill leachates and gases", Groundwater, 34(5), pp. 827-836, 1996.

https://doi.org/10.1111/j.1745-6584.1996.tb02077.x

[53] Hornibrook, E. R. C., Longstaffe, F. J., Fyfe, W. S. "Factors Influencing Stable Isotope Ratios in $\mathrm{CH}_{4}$ and $\mathrm{CO}_{2}$ Within Subenvironments of Freshwater Wetlands: Implications for $\delta$-Signatures of Emissions", Isotopes in Environmental and Health Studies, 36(2), pp. 151-176, 2000. https://doi.org/10.1080/10256010008032940

[54] Hornibrook, E. R. C., Longstaffe, F. J., Fyfe, W. S. "Evolution of stable carbon-isotope compositions for methane and carbon dioxide in freshwater wetlands and other anaerobic environments", Geochimica et Cosmochimica Acta, 64(6), pp. 1013-1027, 2000. https://doi.org/10.1016/S0016-7037(99)00321-X

[55] Games, L. M., Hayes, J. M. "On the mechanisms of $\mathrm{CO} 2$ and CH4 production in natural anaerobic environments", In: Nriagu, J. O. (ed.) Environmental Biogeochemistry, V.1, Carbon, Nitrogen, Phosphorus, Sulfur and Selenium Cycles, Ann Arbor Science Publishers, Ann Arbor, MI, USA, 1976, pp. 1-73.

[56] Baedecker, M. J., Back, W. "Hydrogeological Processes and Chemical Reactions at a Landfill", Groundwater, 17(5), pp. 429-437, 1979. https://doi.org/10.1111/j.1745-6584.1979.tb03338.x

[57] Kerfoot, H. B., Baker, J. A., Burt, D. M. "The use of isotopes to identify landfill gas effect on groundwater", Journal of Environmental Monitoring, 6, pp. 896-901, 2003. https://doi.org/10.1039/b310351j

[58] Liptay, K., Chanton, J., Czepiel, P., Mosher, B. "Use of stable isotopes to determine methane oxidation in landfill cover soils", Journal of Geophysical Research: Atmospheres, 103(D7), pp. 8243-8250, 1998. https://doi.org/10.1029/97JD02630

[59] Abichou, T., Powelson, D., Chanton, J., Escoriaza, S., Stern, J. "Characterization of Methane Flux and Oxidation at a Solid Waste Landfill", Journal of Environmental Engineering, 132(2), pp. 220-228, 2006.

https://oi.org/10.1061/(ASCE)0733-9372(2006)132:2(220)

[60] Bergamaschi, P., Lubina, C., Königstedt, R., Fischer, H., Veltkamp, A. C., Zaagstra, O. "Stable isotope signatures ( $\delta 13 \mathrm{C}, \delta \mathrm{D})$ of methane from European landfill sites", Journal of Geophysical Research: Atmospheres, 103(D7), pp. 8251-8265, 1998. https://doi.org/10.1029/98JD00105

[61] Börjesson, G., Chanton, J., Svensson, B. H. "Methane Oxidation in Two Swedish Landfill Covers Measured with Carbon-13 to Carbon-12 Isotope Ratios", Journal of Environmental Quality, 30(2), pp. 369-376, 2001.

https://doi.org/10.2134/jeq2001.302369x

[62] Whiticar, M. J., Faber, E., Schoell, M. "Biogenic methane formation in marine and freshwater environments: $\mathrm{CO}_{2}$ reduction vs. acetate fermentation - Isotope evidence", Geochimica et Cosmochimica Acta, 50(5), pp. 693-709, 1986. https://doi.org/10.1016/0016-7037(86)90346-7
[63] Conrad, R. "Control of Methane Production in Terrestrial Ecosystems", In: Andreae, M. O., Schimel, D. S. (eds.) Exchange of Trace Gases between Terrestrial Ecosystems and the Atmosphere, John Wiley, New York, NY, USA, pp. 39-58, 1989. https://doi.org/10.1007/BF00024600

[64] Whiticar, M. J. "Carbon and hydrogen isotope systematics of bacterial formation and oxidation of methane", Chemical Geology, 161(1-3), pp. 291-314, 1999.

https://doi.org/10.1016/S0009-2541(99)00092-3

[65] Christophersen, M., Kjeldsen, P. "Field investigations of methane oxidation in soil adjacent to an old landfill", presented at the 1st Intercontinental Landfill Research Symposium, Luleå University of Technology, Luleå, Sweden, Dec, 11-13, 2000.

[66] Christophersen, T. H., Kjeldsen, P. "Factors governing lateral gas migration and subsequent emission in soil adjacent to an old landfill", presented at the 1st Intercontinental Landfill Research Symposium, Luleå University of Technology, Luleå, Sweden, Dec, 11-13, 2000.

[67] Ostera, H. A., Cordero Otero, R. R., Panarello, H. O., Valencio, S. A., Villarosa, G. "Isotope and Geochemical evidences on the evolution of landfills, Bariloche, Argentina", In: 5th South American Symposium on Isotope Geology, Sao Paulo, Brazil, 2006, pp. 508-510.

[68] Rettenberger, G., Stegmann, R. "Landfill gas components", In: Christensen, T. H., Cossu, R., Stegmann, R. (eds.) Landfilling of Waste: Biogas, E \& FN Spon, London, UK, 1996, pp. 51-58.

[69] Eklund, B., Anderson, E. P., Walker, B. L., Burrows, D. B. "Characterization of Landfill Gas Composition at the Fresh Kills Municipal Solid-Waste Landfill", Environmental Science and Technology, 32(15), pp. 2233-2237, 1998. https://doi.org/10.1021/es980004s

[70] Rasi, S., Läntelä, J., Rintala, J. "Trace compounds affecting biogas energy utilisation - A review", Energy Conversion and Management, 52(12), pp. 3369-3375, 2011. https://doi.org/10.1016/j.enconman.2011.07.005

[71] Kim, K.-H., Baek, S. O., Choi, Y.-J., Sunwoo, Y., Jeon, E.-C., Hong, J. H. "The Emissions of Major Aromatic Voc as Landfill Gas from Urban Landfill Sites in Korea", Environmental Monitoring and Assessment, 118, pp. 407-422, 2006. https://doi.org/10.1007/s10661-006-1507-5

[72] Kim, K.-H. "Emissions of reduced sulfur compounds (RSC) as a landfill gas (LFG): A comparative study of young and old landfill facilities", Atmospheric Environment, 40(34), pp. 6567-6578, 2006. https://doi.org/10.1016/j.atmosenv.2006.05.063

[73] Renou, S., Givaudan, J. G., Poulain, S., Dirassouyan, F., Moulin, P. "Landfill leachate treatment: Review and opportunity", Journal of Hazardous Materials, 150(3), pp. 468-493, 2008. https://doi.org/10.1016/j.jhazmat.2007.09.077

[74] Alvarez-Vazquez, H., Jefferson, B., Judd, S. J. "Membrane bioreactors vs conventional biological treatment of landfill leachate: a brief review", Journal of Chemical Technology and Biotechnology, 79(10), pp. 1043-1049, 2004. https://doi.org/10.1002/jctb.1072 